\title{
VASECTOMY: LONG-TERM EFFECTS IN THE RHESUS MONKEY*
}

\author{
NANCY J. ALEXANDER \\ Oregon Regional Primate Research Center, \\ 505 N.W. 185th Avenue, Beaverton, Oregon 97005, U.S.A.
}

(Received 16th November 1971, accepted 6th December 1971)

\begin{abstract}
Summary. Long-term vasectomy of rhesus monkeys causes many morphological and functional changes in the epididymis, particularly in the ductuli efferentes. In intact animals, the epithelium of the ductuli efferentes consists of about equal numbers of ciliated and non-ciliated cells. Normally, in their apical portions, the ciliated cells contain lipid complexes associated with mitochondria. Spermatozoa are less frequently found in the lumen of the ductuli but are packed together and stored in large numbers in the caudal portion of the epididymis. In vasectomized animals, the ductuli enlarge as much as four times in diameter, and the epithelial basal lamina (normally 500 to $700 \AA$ ) thickens considerably (up to $3 \cdot 2 \mu \mathrm{m}$ ). The number of ciliated cells is greatly reduced and in those remaining, the characteristic lipid complexes are absent. Spermatozoa become agglutinated in the lumen of the ductuli where they are ingested by macrophages. Fluorescein-labelled antibody and electron microscopy show the thickened basal lamina to be in the site of antigen-antibody complexing. It is postulated that long-term vasectomy results in an autoimmune response to spermatozoa that may aid in the disposal of the many spermatozoa still being produced by the testes but lacking an exit passage.
\end{abstract}

\section{INTRODUCTION}

Vasectomy, a widespread birth control measure, was first attempted in 1823 by Astley Cooper on dogs (Jhaver \& Ohri, 1960). Examination of the spermfilled testes and epididymides 6 years later demonstrated that vasectomy had not prevented spermatogenesis. It has been repeatedly demonstrated since that after vasectomy, spermatozoa are still produced although the exit passage is no longer present. The morphological effects of obstruction of the vas deferens have not been adequately investigated, interest having been largely centred on the effect of ligation of the vasa deferentia on the testes. However, after vasectomy, changes occur throughout the entire male duct system but, in the rhesus monkey at least, are most prevalent in the ductuli efferentes, a site well removed from the area of the surgical ligation. This study is concerned with the longterm rather than the immediate structural changes of the ductuli efferentes

* Publication No. 594 of the Oregon Regional Primate Research Center. 
associated with vasectomy, and the fate of the spermatozoa produced by the testes is discussed.

\section{METHODS}

\section{Electron microscopy}

Biopsies of the ductuli efferentes, and of caput, mid- and cauda epididymidis were taken from normal rhesus, Macaca mulatta, and stumptailed, Macaca speciosa, monkeys and from rhesus monkeys that had been vasectomized 1 month, 3 months, and 3,5 and 7 years previously. During surgery, both ends of the vas deferens in the region cranial to the neck of the scrotum were ligated and a piece of the vas was removed. The tissues were fixed for $2 \mathrm{hr}$ in $0.75 \%$ glutaraldehyde, $4 \%$ formalin, $3.5 \%$ sucrose, and $0.05 \% \mathrm{CaCl}_{2}$ in s-collidine buffer at $\mathrm{pH} 7 \cdot 4$, washed in buffer, post-fixed in $1 \%$ osmium tetroxide, dehydrated in alcohol, and embedded in Araldite. Thick sections were stained with 1\% toluidine blue in $1 \%$ borax. Thin sections were stained with uranyl acetate in alcohol and lead citrate.

\section{Acid phosphatase}

Tissue was prepared for both light and electron microscopy by being fixed in $4.6 \%$ glutaraldehyde in cacodylate buffer for $2 \mathrm{hr}$ and washed in buffer overnight. Sections were cut at $40 \mu \mathrm{m}$ on a freezing microtome, and incubated in Gomori's substrate. Sections for light microscopy were rinsed in acetate buffer, washed in acetic acid, ammonium sulphide and water, and mounted in glycerine jelly. For electron microscopy, sections were put in acetate buffer, then post-fixed in osmium tetroxide, dehydrated and embedded in Araldite.

\section{Fluorescein-labelled antibody}

For the fluorescein-labelled antibody study, samples of ductuli efferentes, epididymis and vas deferens from intact and vasectomized animals were placed in $n$-hexane cooled by acetone and dry ice. The biopsies were stored in liquid nitrogen. Sections were cut at $10 \mu \mathrm{m}$ on a cryostat and, after drying, were fixed for $5 \mathrm{~min}$ in $95 \%$ ethanol, rinsed in phosphate-buffered saline, dried, and stained overnight while chilled. They were then rinsed in phosphatebuffered saline, dried and mounted with buffered glycerol. The rabbit antihuman immunoglobulins were purchased from Melpar, Springfield, Virginia, the goat antihuman C'3 was from the Cordis Laboratories, Miami, Florida. The sections were stained with anti-C' 3 and anti-IgG conjugated with fluorescein isothiocyanate which had been adsorbed with kidney powder to avoid non-specific staining. Sections were viewed with a Zeiss Ultraphot fluorescence microscope with barrier 53 and exciter 12 filters.

\section{Daily human sperm output}

A rough estimate of the daily sperm output in man was needed to determine the amount of sperm resorption after vasectomy. The procedure of Freund (1968) was followed. Two men ejaculated at least twice daily for a week before collection to eliminate any spermatozoa stored in the epididymis. The next 
five ejaculates on the next 5 consecutive days were collected and allowed to liquefy for $45 \mathrm{~min}$ at $37^{\circ} \mathrm{C}$, and a sample was counted on a haemocytometer. The total counts of each day were averaged. The monkey was not a good model for this study because of the infeasibility of repeated frequent electroejaculations and because of the possibility of masturbation.

\section{RESULTS}

The ductuli efferentes of rhesus and stumptailed macaques consist of twelve tubules about $1 \mathrm{~cm}$ long that connect the rete testis with the coiled caput epididymidis. Numerous blood vessels interweave within the surrounding connective tissue. The ductuli range in diameter from $275 \mu \mathrm{m}$ to $350 \mu \mathrm{m}$. Each ductule is composed of a single layer of columnar epithelial cells and is encircled by a 500 - to $800-\AA$ basal lamina. In thin sections, spermatozoa are relatively infrequently encountered within the lumen. The ductule epithelial cells consist of ciliated and non-ciliated cells, at least $50 \%$ of them being ciliated (Pl. 1, Fig. 1). In all respects, the epithelial cells of the rhesus monkey and of the stumptailed macaque are similar. The cytoplasm of the ciliated cells usually stains lightly in thick sections (Pl. 2, Fig. 2). The basal half of these cells is filled with the nucleus; the apical part contains many mitochondria and dense membranebounded granules (Pl. 3, Fig. 4) that resemble lysosomes but are not acidphosphatase-positive.

The non-ciliated cells are columnar ( $25 \mu \mathrm{m}$ high $\times 1 \mu \mathrm{m}$ wide), extending from the base of the ductule epithelium to the lumen (P1. 1, Fig. 1). An elongated nucleus fills the basal part of the cell; many dense granules $(0.06$ to $0.11 \mu \mathrm{m}$ in diameter) are located in the apical part. The non-ciliated cells have apical microvilli with much side-to-side anastomosis (stereocilia).

In intact (non-vasectomized) animals, macrophages are rare throughout the duct system.

The ductuli efferentes of animals vasectomized for 2 or more years have a two- to fourfold increase in diameter, undoubtedly because of being packed with spermatozoa. Ciliated cells remain the same size as in normal animals, although they are greatly reduced in number; in some regions, they disappear entirely. The apical dense granules so common in ciliated cells have vanished. The non-ciliated cells become shorter $(15 \mu \mathrm{m})$ as the duct becomes stretched, and their long stereocilia become reduced to simple microvilli. In a vasectomized animal, the basal lamina, normally around $700 \AA$ thick, undergoes a threefold increase (up to $3.2 \mu \mathrm{m}$ thick) (Pl. 2, Fig. 3). The apical part of all the cells, whether non-ciliated or ciliated, of the ductuli become laden with dense homogeneous granules (Pl. 3, Fig. 5).

Within the ductuli efferentes of the monkeys vasectomized 3,5 and 7 years previously, the spermatozoa become agglutinated as soon as they leave the testis (Pl. 3, Fig. 5 and Pl. 5, Fig. 7) and increase in number in the lumen. Numerous macrophages are present in the ductuli efferentes and can be seen engulfing and digesting spermatozoa (Pl. 4, Fig. 6). These macrophages are not found in the lumina of animals vasectomized only 1 or 3 months previously. In the cauda epididymidis of monkeys vasectomized 3,5 and 7 years previously, 
few spermatozoa are seen. Macrophages are abundant in this region of the duct, but the remnants of spermatozoa within the macrophages are no longer recognizable (PI. 5, Fig. 8).

Because of the agglutinated appearance of the spermatozoa and because previous work (Alexander, 1972) has demonstrated high titres of spermagglutinin antibodies in animals with long-term vasectomies, a fluorescein-labelled antibody was used to pinpoint the site of antigen-antibody complexing. Both $\mathrm{C}^{\prime} 3$ and IgG antibodies were conjugated with fluorescein and tested on tissue slices from an intact animal and from one vasectomized 3 years before. Some orange autofluorescent granules were seen in the apical cytoplasm of cells lining the duct in tissue from both the experimental and control animals; however, no green-yellow fluorescein label was seen in the non-vasectomized control animal. In the vasectomized animal, the basement membrane surrounding the sections of ductuli fluoresced green-yellow. In sections from the cauda epididymidis, the spermatozoa themselves exhibited some fluorescence which

\section{EXPLANATION OF PLATES 1 TO 5}

PLATE 1

Fig. 1. Electron micrograph of part of a cross-section of an efferent duct from an intact adult stumptailed macaque, showing a ciliated cell and an adjacent non-ciliated cell that contains dense granules (SG). All cells rest upon a basal lamina $(B L) . \times 10,000$.

\section{PLATE 2}

FIG. 2. Light micrograph showing part of a cross-section of an efferent duct from an adult rhesus monkey. Note the large proportion of ciliated cells. $\times 950$.

Frg. 3. Electron micrograph of the basal part of an efferent duct from a rhesus monkey vasectomized 7 years previously. The duct has taken on a pseudostratified appearance. The underlying basal lamina (BL) is considerably thickened (compare with Pl. 1, Fig. 1). $\times 7400$.

\section{PLATE 3}

FIG. 4. The apical area of a ciliated cell from the efferent ductules of a normal rhesus monkey. Basal bodies (BB) and a ciliary rootlet (GR) are visible in the upper right corner. The dense conglomerate granules (DCG) which appear to have a lipid component are a hallmark of ciliated cells in the normal animal, but these granules disappear after vasectomy. In the lower right corner is the apical edge of a secretory cell. Mitochondria $(\mathrm{M})$, nucleus $(\mathrm{N}) . \times 18,000$.

Fig. 5. Apical area of cells from the efferent duct of a rhesus monkey vasectomized 5 years previously. All cells, whether non-ciliated or ciliated, contain dense amorphous granules (DG). The elaborations in the apical cytoplasm (Fig. 4) are much reduced and the stereocilia take the form of stubby microvilli. In the lumen, the spermatozoa (S) are agglutinated and abnormal. $\times 10,000$.

\section{PLATE 4}

Fig. 6. Numerous macrophages are present throughout the lumina of the ductuli efferentes and caput epididymidis of rhesus monkeys with a long-term vasectomy. This micrograph shows a macrophage containing many newly engulfed and partially digested spermatozoa. Nucleus (N). $\times 14,600$.

\section{PLATE 5}

FrG. 7. Electron micrograph of the lumen of an efferent duct of a rhesus monkey with a long-term vasectomy. The spermatozoa are all clumped or agglutinated. This phenomenon may be caused by spermagglutinin titres in the serum that rise after vasectomy. $\times 18,500$.

Fig. 8. In the cauda epididymidis of rhesus monkeys with a long-term vasectomy, no recognizable spermatozoa are present, even in macrophages. This macrophage from the caudal region contains only residues. $\times 24,000$. 


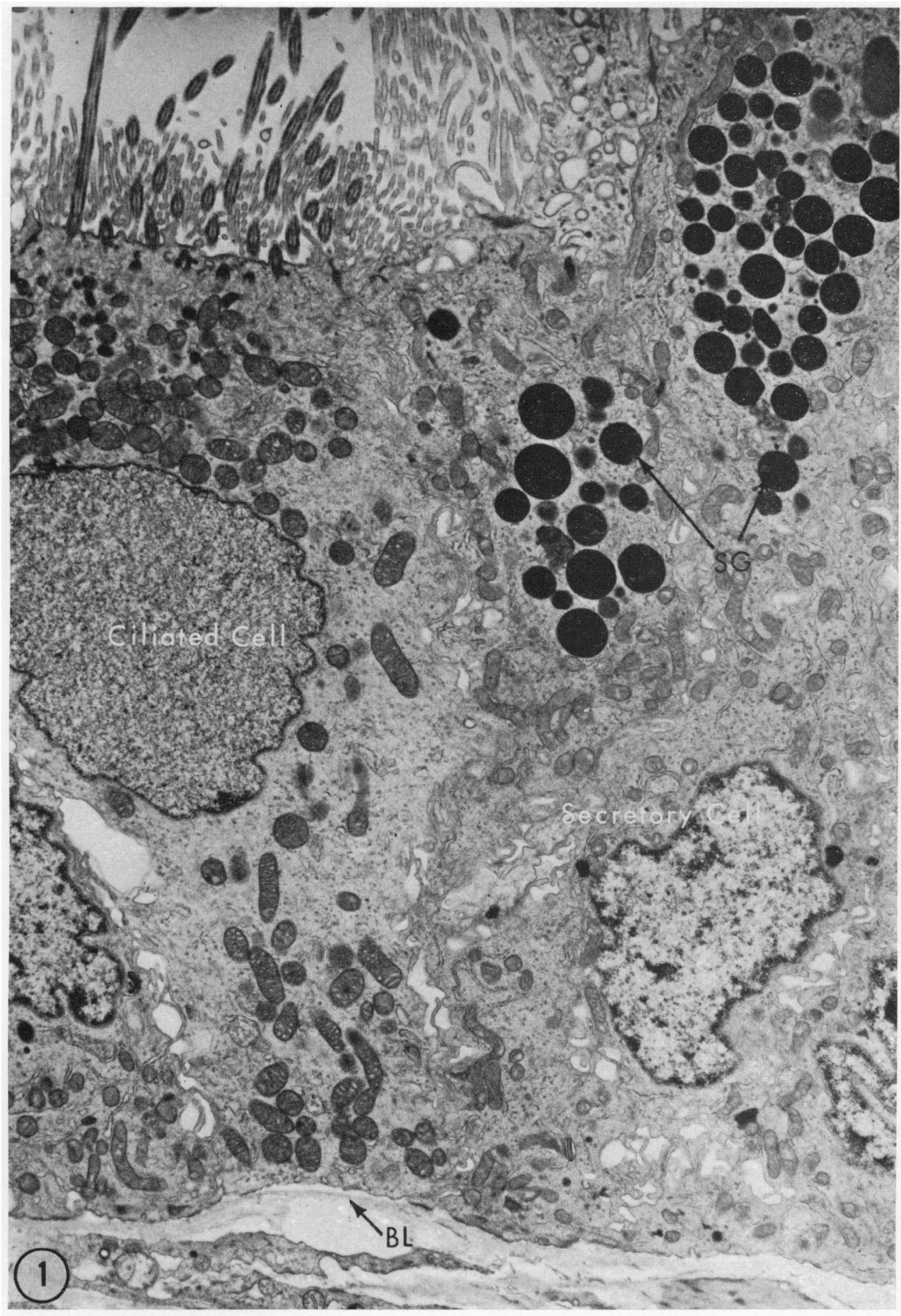


PI.AIE 2
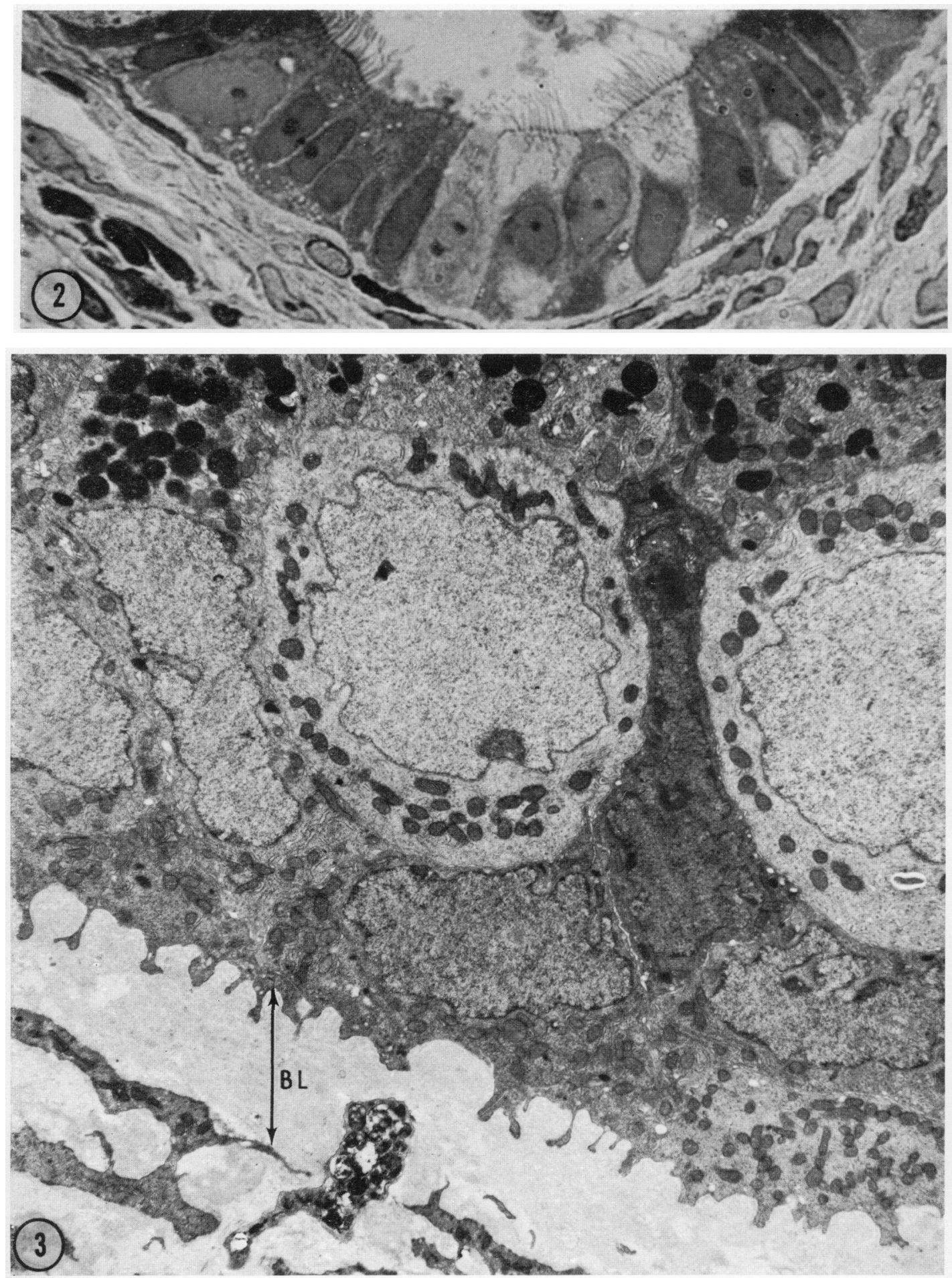

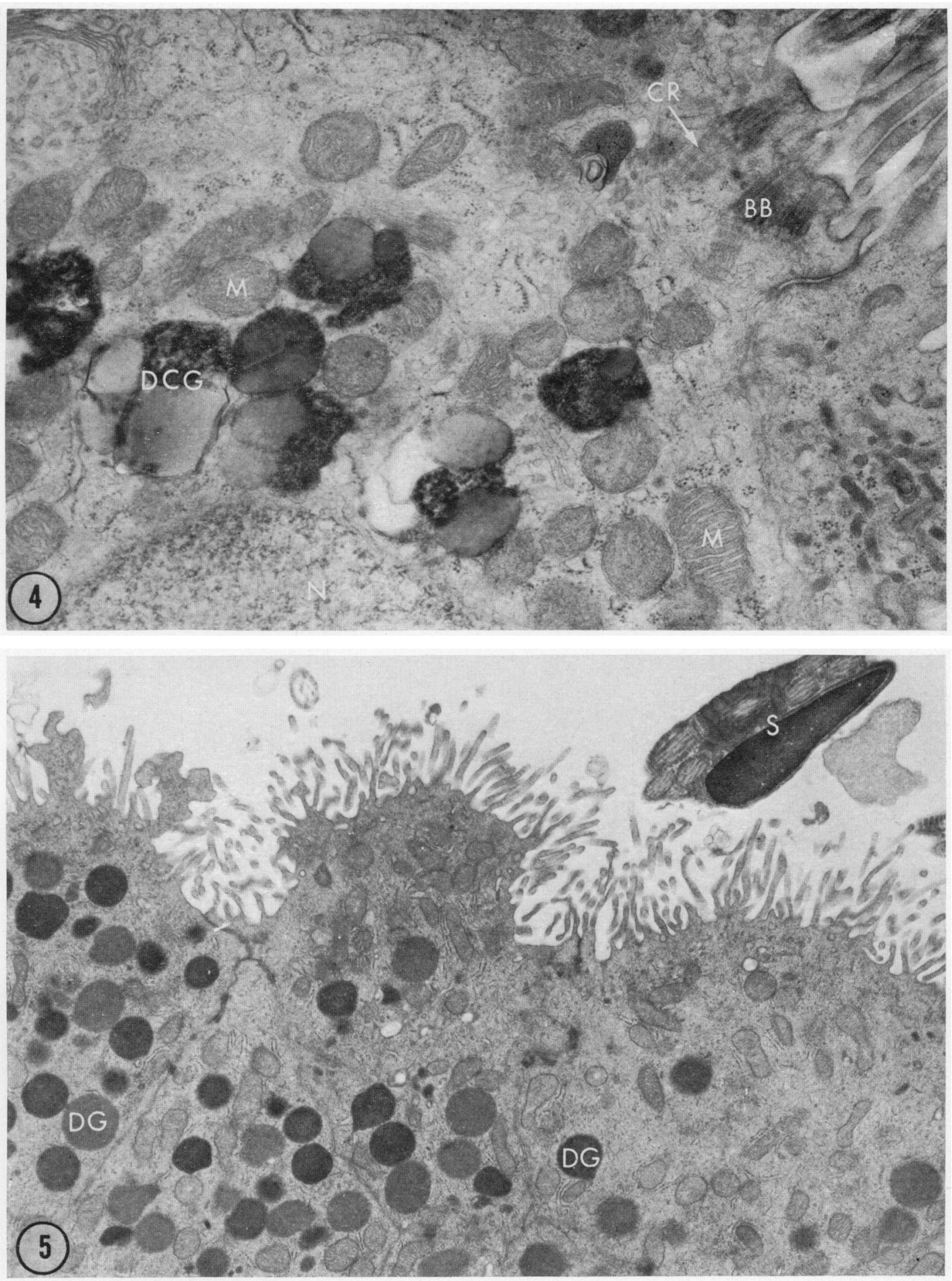


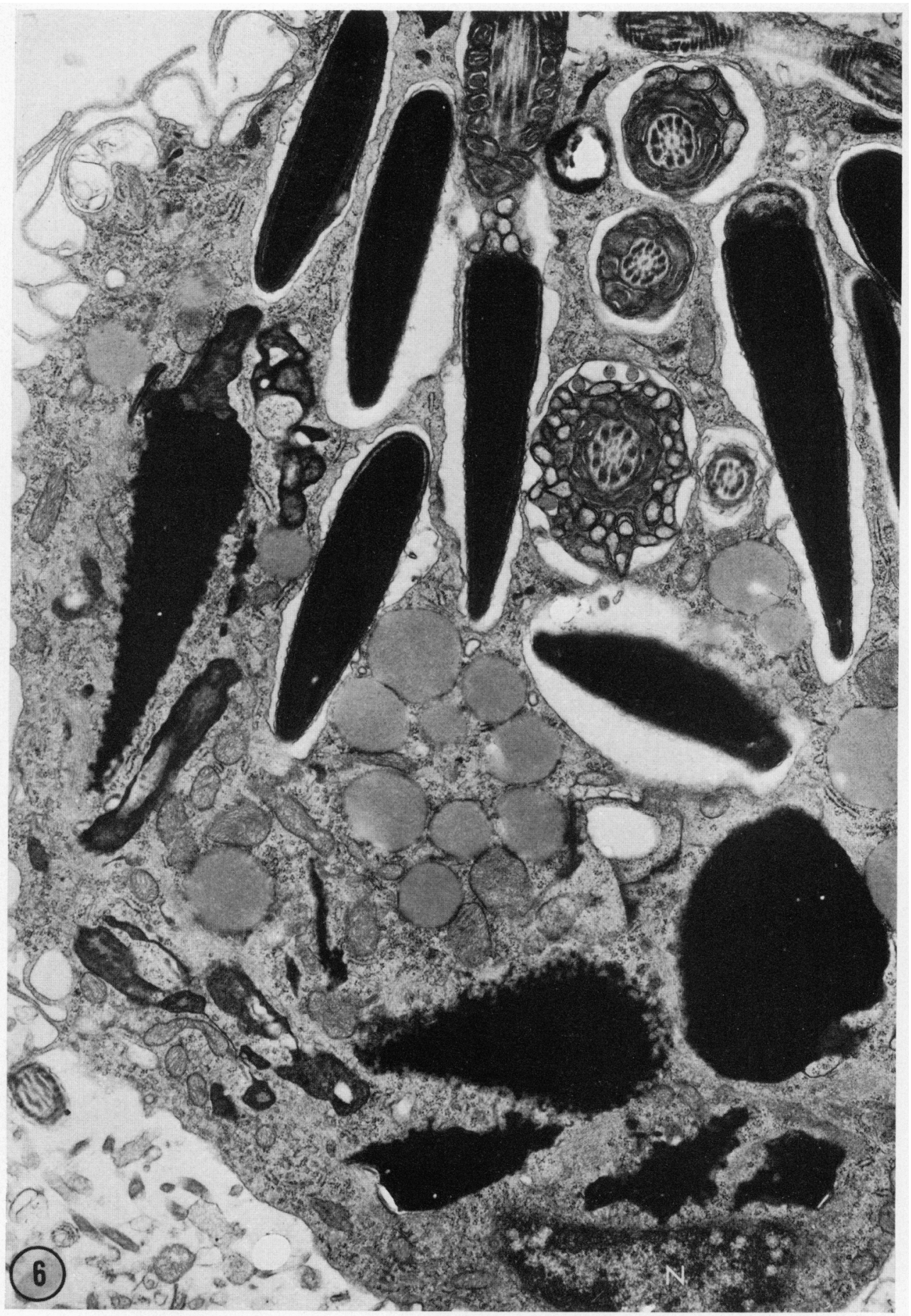


PLA'TE 5
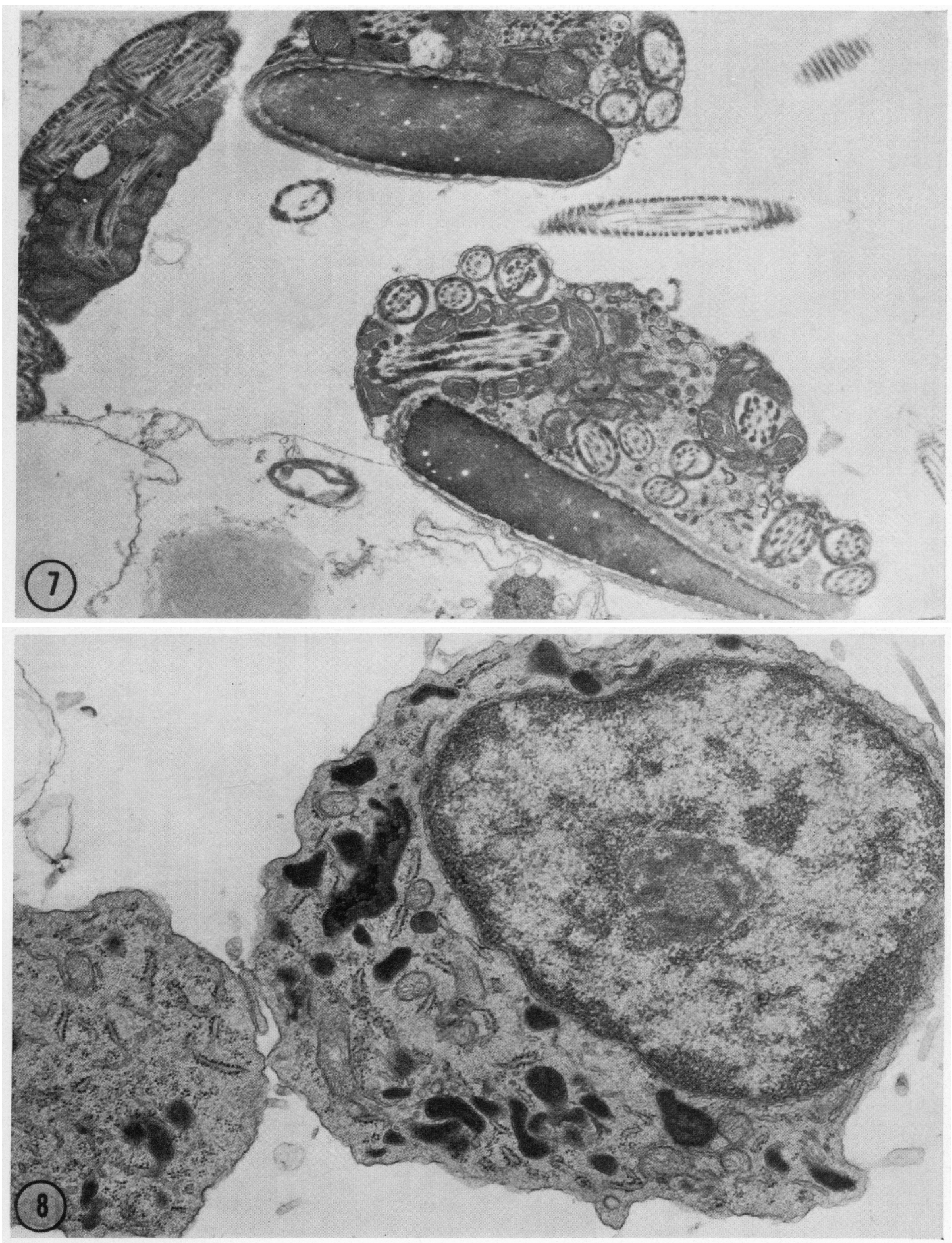
was lacking in the control animal. The fluorescence study with antihuman IgG showed that significant levels of IgG were present in the area; the non-vasectomized animal also showed some IgG present but much less. However, only the vasectomized animal showed staining with antihuman $\mathrm{C}^{\prime} 3$. This strongly indicates (1) the formation of immune complexes, (2) a local Arthus reaction, and (3) the autoimmune nature of the changes observed.

Since the spermatozoa from a vasectomized animal must be entirely absorbed, an estimate of sperm output had to be determined. In man, the daily sperm output varies considerably but, generally speaking, about 50,000 spermatozoa are produced every minute. Comparisons of single ejaculates from men and monkeys indicated that the number of spermatozoa per ejaculate for monkeys is about four times that of men (average number of spermatozoa per monkey ejaculate is $5 \cdot 3425 \times 10^{8}$ ). This estimate does not take into account those spermatozoa that are resorbed en route.

\section{DISGUSSION}

Spermatozoa are neither motile (Gaddum, 1968) nor fertile (Igboeli \& Foote, 1969) when they leave the testis but become so only after passage through the ductuli efferentes and the epididymis. The ductuli are more than a passage-way for the transportation of spermatozoa; they probably push the spermatozoa (1) by muscular contraction, (2) by fluid production and flow from within the seminiferous tubules (Toothill \& Young, 1931), or (3) by means of the many ciliated cells that are thought to have a vortical flushing action (ZawischOssenitz, 1933; Kwiet, 1966). The millions of spermatozoa produced daily pass rapidly through this region; hence the low number seen in a thin section of lumen.

The ductuli efferentes and caput epididymidis are active sites of absorption (Young, 1933); in the ram, 99\% of testicular fluids are resorbed in this region (Crabo, 1965). In other species, colloidal particles and peroxidase have been shown to be selectively incorporated into the non-ciliated cells of the ductuli efferentes by micropinocytosis (Sedar, 1966; Montorzi \& Burgos, 1967) as is trypan blue (Shaver, 1954). Moreover, since spermatozoa are always moved in a fluid medium, the ductuli efferentes and caput epididymidis must add some secretion products to the seminal plasma.

With vasectomy, these same processes continue but the spermatozoa produced by the seminiferous tubules now lack an exit passage. Although the ligated duct increases two to four times in diameter, spermatogenesis itself is not affected by vasectomy (Moore \& Quick, 1924; Amann, 1962; Glover, 1969) except for a possible slight decrease in sperm production (Swanson \& Hafs, 1969; Igboeli \& Rakha, 1970). All studies on testicular tissue indicate that little or no change is associated with long-term vasectomy (Wheelon, 1921; Smith, 1962; Kubota, 1969). After vasectomy, since thousands of spermatozoa are still being produced every minute, they must be reabsorbed somewhere between the testis and the vas deferens. The ductuli efferentes and the epididymis are the most probable site of resorption.

In intact animals, spermatozoa are absorbed as part of a normal process. 
Orgebin-Crist (1968) estimated that at least $50 \%$ of all spermatozoa produced by the rabbit were resorbed in the epididymis. Similarly, Amann (1970) stated that, in the rabbit, daily sperm output is only $60 \%$ of daily sperm production. Resorption occurs primarily in the caudal portion of the epididymis. The fact that broken spermatozoa are most common in the body of the epididymis (Glover, 1961; Amann \& Almquist, 1962) and relatively uncommon in the ejaculate, supports this assumption. The rate of sperm resorption is thought to depend on the number of spermatozoa in the cauda epididymidis (Amann \& Almquist, 1962); therefore resorption would occur more rapidly in sexually rested animals. The actual mode of resorption is unknown, since there appear to be no partially degenerated spermatozoa in the epididymis, and epididymal cells do not appear to be actively involved in phagocytosis (Fulka, Kopečný \& Koefoed-Johnsen, 1971). Normally, there are not many phagocytic cells in the lumen of the epididymis.

After vasectomy, however, the number of macrophages in the epididymis increases markedly, particularly in the ductuli efferentes and caput epididymidis. These macrophages actively engulf and degrade spermatozoa and, thus, are instrumental in the rapid removal of the trapped spermatozoa. This process is essentially completed in the caput epididymidis of vasectomized animals; few whole spermatozoa are contained in the cauda epididymidis where macrophages have digested rather than newly ingested sperm residues. Phagocytosis of spermatozoa is not limited to the monkey but occurs in man after ligation of the vas deferens (Phadke, 1964). Thus, the main method of sperm removal after ligation seems to be phagocytosis by macrophages.

After vasectomy, the level of circulating spermagglutinins rises (Alexander, 1972) and increases with time. Sera of animals vasectomized 7 years ago have an antibody titre which is several times higher than that of animals vasectomized more recently. The following sequence probably occurs in vasectomized animals. Macrophages invade the epididymis, ingest the spermatozoa, and then transfer either an antigen or information about the antigen to those cells destined to make antibodies. These antibodies may then aid the macrophages to recognize the cells to be ingested. As the antibody titre increases, the spermatozoa probably undergo a greater degree of agglutination in the ductuli efferentes and caput epididymidis. This hypothesis is supported by the fact that biopsies from monkeys with long-term vasectomies showed that all the spermatozoa within the lumina were agglutinated; biopsies of the same region from animals recently vasectomized ( 1 and 3 months) showed no agglutination. Antigenantibody complexing revealed by fluorescent-labelled antibody occurs in the basement membrane, indicating that immunoglobulin complexes are precipitating in this area. The changes following vasectomy may be initiated by a local inflammatory reaction which causes an infiltration of polymorphonuclear granulocytes. The presence of $\mathrm{C}^{\prime} 3$ in the basement membrane indicates that this antigen-antibody precipitate binds complement and therefore the immune reaction involved is an Arthus reaction. Electron microscopy shows that, after vasectomy, the basal lamina gradually becomes thickened, an indication of an autoimmune antibody reaction to spermatozoa resulting from vasectomy. Thickening of the basal lamina may be directly related to the amount of anti- 
body present. This is supported by the fact that the spermagglutinin titre in the serum of monkeys rises with the time elapsing after a vasectomy (Alexander, 1972) and, likewise, basement membrane thickening is not apparent until several years after vasectomy. These changes in the epididymis are certainly of an autoimmune nature and may become more progressive with time, possibly involving other areas of the body.

Another area of consideration brought up by this study concerns the possibility of successful surgical re-anastomosis after long-term vasectomy in man. High spermagglutinin titres have been demonstrated more frequently in sterile men (Fjällbrant, 1968), causing reduced motility and agglutination of spermatozoa (Fjällbrant \& Obrant, 1968). These same agglutinins are present in vasectomized animals (Alexander, 1972). Cases of pregnancy after repair of vasectomies in man are lower than might be expected (Dubin \& Amelar, 1971). The autoimmune changes both in the epididymis and in the serum after longterm vasectomy may function in reducing the chance for successful pregnancy after surgical re-anastomosis of the vas deferens.

\section{ACKNOWLEDGMENTS}

The author sincerely thanks Dr A. Malley and Dr B. Wilson for their willing assistance and advice, and Miss Jeanne Hren for her excellent technical help. This study was supported by NIH Grants No. HD05180 and FR00163.

\section{REFERENCES}

Alexander, N. J. (1972) Long-term effects of vasectomy in the rhesus monkey. Biol. Reprod. 7 (2), Abst. 89.

Amann, R. P. (1962) Reproductive capacity of dairy bulls. III. The effect of ejaculation frequency, unilateral vasectomy, and age on spermatogenesis. Am. F. Anat. 110, 49.

Amann, R. P. (1970) The male rabbit. IV. Quantitative testicular histology and comparisons between daily sperm production as determined histologically and daily sperm output. Fert. Steril. $21,662$.

Amann, R. P. \& ALmQuist, J. O. (1962) Reproductive capacity of dairy bulls. VI. Effects of unilateral vasectomy and ejaculation frequency on sperm reserves; aspects of epididymal physiology. $\mathcal{F}$. Reprod. Fert. 3, 260.

CRabo, B. (1965) Studies on the composition of epididymal content in bulls and boars. Acta vet. scand. 6, Suppl. 5.

Dubin, L. \& Amelar, R. D. (1971) Etiologic factors in 1294 consecutive cases of male infertility. Fert. Steril. 22, 469.

FJällbRant, B. (1968) Sperm agglutinins in sterile and fertile men. Acta obstet. gynec. scand. 47, 102.

FJällbrant, B. \& OBRant, O. (1968) Clinical and seminal findings in men with sperm antibodies. Acta obstet. gynec. scand. 47, 451.

FreUnd, M. (1968) Semen analysis. In: Progress in Infertility. Eds. S. J. Behrman and R. W. Kistner. Little, Brown \& Co., Boston.

Fulka, J., KopeČnÝ, V. \& KoEfOED-Johnsen, H. H. (1971) Tritium activity in spermatozoa and epididymal epithelium after application of thymidine-methyl- $\mathrm{H}^{3}$ and passage blocking by ligature. Fert. Steril. 22, 119.

GADDUM, P. (1968) Sperm maturation in the male reproductive tract: development of motility. Anat. Rec. 161, 471.

Glover, T. D. (1961) Disintegrated spermatozoa from the epididymis. Nature, Lond. 190, 185.

Glover, T. D. (1969) Some aspects of function in the epididymis. Experimental occlusion of the epididymis in the rabbit. Int. F. Fert. 14, 216.

Igboeli, G. \& Foote, R. H. (1969) Maturation and aging changes in rabbit spermatozoa isolated by ligatures at different levels of the epididymis. Fert. Steril. 20, 506.

IgBoEl, G. \& RAKHA, A. M. (1970) Bull testicular and epididymal functions after long-term vasectomy. F. Anim. Sci. 31, 72. 
JHAver, P. S. \& Ohri, B. B. (1960) The history of experimental and clinical work on vasectomy. $\mathcal{J}$. int. Coll. Surg. 33, 482.

KuвотA, R. (1969) Electron microscopic studies on the testis after vasectomy in rats and men. $\mathcal{F a p . \mathcal { F }}$. Urol. 60, 373.

KwIET, K. P. (1966) Úber Strömungsfiguren im Nebenhoden der weissen Ratte. Gegenbaurs morph. $\mathcal{F b . ~}$ $108,255$.

Montorzi, N. M. \& Burgos, M. H. (1967) Uptake of colloidal particles by cells of the ductuli efferentes of the hamster. Z. Zellforsch. mikrosk. Anat. 83, 58.

Moore, G. R. \& Quick, W. J. (1924) Properties of the gonads as controllers of somatic and psychical characteristics. VII. Vasectomy in the rabbit. Am. F. Anat. 34, 317.

ORGEBIN-CRIST, M. C. (1968) Gonadal and epididymal sperm reserves in the rabbit: estimation of the daily sperm production. 7 . Reprod. Fert. 15, 15.

Phadke, A. M. (1964) Fate of spermatozoa in cases of obstructive azoospermia and after ligation of vas deferens in man. 7. Reprod. Fert. 7, 1.

Sedar, A. (1966) Transport of exogenous peroxidase across the epithelium of the ductuli efferentes. $\mathcal{F}$. Cell Biol. 31, 102A.

Shaver, S. L. (1954) The role of stereocilia in removing India ink particles from the lumen of the rat epididymis. Anat. Rec. 119, 177.

Smrтr, G. (1962) The effects of the ligatures of the vasa efferentia and vasectomy on testicular function in the adult rat. 7. Endocr. 23, 385.

Swanson, L. V. \& Hafs, H. D. (1969) Testicular and epididymal sperm numbers in unilaterally vasoligated rabbits. Proc. Soc. exp. Biol. Med. 131, 763.

Tootritu, M. C. \& Younc, W. C. (1931) The time consumed by spermatozoa in passing through the ductus epididymidis of the guinea-pig as determined by means of India-ink injections. Anat. Rec. $50,95$.

WheELON, H. (1921) The microscopic appearance of two testes nine months following unilateral vasectomy. Endocrinology, 5, 307.

Young, W. G. (1933) Die Resorption in den ductuli efferentes der Maus und ihre Bedeutung für das Problem der Unterbindung im Hoden-Nebenhodensystem. Z. Zellforsch. mikrosk. Anat. 17, 729.

Zawisch-Ossenitz, G. (1933) Der Flimmerstrom in den Ductuli efferentes das Hodens und die Bewegung der Spermien. Z. mikrosk.-anat. Forsch. 32, 84. 